821.163.41.09:398

https://doi.org/10.18485/msc.2018.47.2.ch4

Јасмина С. ЈОКИЋ ${ }^{*}$

Универзитет у Новом Саду

Филозофски факултет
Оригинални научни рад

Примљен: 6. 11. 2017.

Прихваћен: 27. 12. 2017.

\title{
КАРНЕВАЛИЗАЦИЈА СВАДБЕ У УСМЕНИМ ДРАМСКИМ ОБЛИЦИМА*
}

\begin{abstract}
У раду се полази од Бахтиновог тумачења карневала као другог, празничног живота народа, те поступка карневализаиије, односно транспоновања карневалског - смеховног начела у различите уметничке форме. Стога ће предмет проучавања у овом раду бити различити елементи карневализације у тзв. народним играма, који представљају рудиментарне форме усмене драме. На разнородној етнографској грађи и записима драмских игара и драмских елемената обреда који су се изводили у току зимског периода (тзв. месојеђа/ месница и поклада), разматраће се они примери у којима се на шаљив начин инсценира свадба, која иначе представља један од кључних и најкомплекснијих обреда прелаза у нашој традиционалној култури. Уочљиво је да се у усменој драми на типски начин приказују главни учесници свадбе, при чему су обавезно присутни елементи инверзија полова помоћу прерушавања (ритуална травестија), хиперболизација телесности (посебно доњих делова тела и полних органа), ласцивно понашање и опсцени говор (псовке, шаљиви благослови и клетве итд.), што су све типични елементи традиционалне смеховне културе.

Кључне речи: Михаил Бахтин, карневал, карневализација, ритуални смех, обреди прелаза, месојеђе, покладе, усмени драмски облици, шаљива свадба.
\end{abstract}

Говорећи о карневалским светковинама у западној Европи, Бахтин наглашава да је то „drugi” или „praznički život” народа, који се од свакодневног разликује пре свега по томе што је „organizovan na principu smeha” (в. Бахтин 1978: 13). ${ }^{1}$ У нашој традиционалној култури овим светковинама аналогни су период месојеђа, Беле недеље и поклада, ${ }^{2}$ који су представљали изузетно

\footnotetext{
*jasmina.jokic@ff.uns.ac.rs

** Рад је настао у оквиру пројекта Аспекти идентитета и њихово обликовање у српској књижевности (178005), који се уз финансијску подршку Министарства просвете и науке РС спроводи на Одсеку за српску књижевност Филозофског факултета у Новом Саду.

${ }^{1}$ Бахтинове поставке о односу карневала и народне смеховне (празничне) културе, као и могућност њихове примене у усменом стваралаштву разматра се у: Карановић, Јокић 2009.

${ }^{2} \mathrm{Mecojeђе/Меснице} \mathrm{је} \mathrm{време} \mathrm{између} \mathrm{два} \mathrm{најдужа} \mathrm{поста} \mathrm{-} \mathrm{божићног} \mathrm{и} \mathrm{ускршњег,} \mathrm{односно} \mathrm{из-}$ међу Божића и поклада. Бела недеља је назив за седмицу пред ускршњи пост. Последњи дан ове седмице назива се беле/велике/заврине/проштене или ускршње покладе. Под појмом покладе у
} 
важан сегмент у систему обележавања и светковања преломних фаза кроз које пролази природа током годишњег циклуса. Наиме, поменути период везан за време око зимске краткодневице или непосредно после ње, а обредно весеље и смех који су притом били обавезни представљају остатак древних ратарских обредних светковина чија је сврха била да „pomognu zemlji da se probudi za novi život i novo rađanje" (Проп 1984: 149). Због тога су се и у нашој фолклорној традицији управо тада изводили обреди у којима су доминантни елементи фолклорне драме: крећу се маскиране поворке по селу или се изводе игре на сијелима (дневним и ноћним, у затвореном или на отвореном простору). ${ }^{3}$ Понегде су се игре у затвореном простору и маскирани опход села одигравали паралелно (в. Мићевић 1952: 156).

Чланови коледарске дружине често су маскирани тако да на шаљив начин представљају свадбу, те су и њихови називи и подела улога у складу са овом идејом: младожења, млада/невеста/снашка, двојица деда или дед $и$ баба (в. Филиповић, Томић 1955: 93-94; Ђорђевић 1958: 328-329; Николић Стојанчевић 1974: 534; Антонијевић 1997: 57; Зечевић 2008: 84). Притом је једна од најзанимљивијих фигура међу њима млада, коју представља мушкарац (обично леп младић) преобучен у свакидашње женско рухо, а уз то се повеже белом марамом и закити неким зимским цветом, док за појас задене преслицу око које је привезано повесмо кучине. Она иде у друштву са дедицом и певачима, и то скромно и мирно, не говори много, него само одговара на питања и за време извођења обреда у кући преде кучину. Због тога што коледарска млатка почиње прести од Св. Игњата, жене по селима отада не преду до Божића. ${ }^{4}$ Има задатак да љуби све старије у кући, да диже са земље танур после свршеног чина, да прима новчане дарове. Понегде се пољуби са неком од присутних девојака, користећи забуну (Ђорђевић 1958: 328-329, 335). Гледаоци током извођења обреда често задиркују невесту, док је чланови коледарске дружине бране, али у појединим варијантама извођења то чине само коледари, или пак младожења (или дедщца) фингирају полни акт са њом. То задиркивање заправо се своди на непристојне радюе (попут штипања, егзибиције одређених делова, мимике која јасно наговештава еротичне жеље), како их дефинише Слободан Зечевић, које су по његовом мишљењу „рудимент некадашњег стварног спајања полова” (Зечевић 2008: 96). Карневалски елементи овде су присутни не само у слободном понашању и отвореном приказивању еротских радњи, него пре свега у замени полног идентитета

најширем смислу подразумева се дан уочи вишедневних или вишенедељних постова (в. Недељковић 1990: 21-26, 152-153, 184 ). Више о историји употребе термина меснице/месојеђе в. у: Бојанин 2009. Обредном смеху и усменим жанровима у поменутом циклусу празника посвећени су радови: Карановић, Јокић 2007 и Карановић, Јокић 2011.

3 О веселој амосфери која влада током одржавања ових скупова и контексту њиховог извођења сведоче и описи појединих сакупљача (в. Милићевић 1894: 183; Холуб 1927: 35). Више података о записима ове врсте народног стваралаштва в. у: Јокић 2011; Јокић 2013.

${ }^{4}$ Предење је трајало за све време јесење-зимског периода, а прекидано је само у време божићних празника. Уколико је обављано у дане када је то забрањено, имало је магијски карактер. Јавља се и као функција неких митолошких бића и исказује везу са оним светом. Мотив да нечиста сила преде одразио се у поворкама машкара, али у том случају предење симболизује богатство и умножавање (CM: 444-445). 
тзв. младе/невесте, чега су свесни и извођачи и гледаоци. Иста врста замене врши се и у покладним маскираним поворкама, које се јављају под различитим именима: оле, олалије, дивље свадбе, дедище, а „имају много заједничких црта или су готово идентичне с коледарским опходима" (Антонијевић 1997: 57). Покладну свадбену поворку чинили су такође млада (у белој хаљини са велом на глави и венцем од трња), младожења (има дуге бркове и браду, понегде јаше на магарцу), стари сват и кум (носе свеће од тулузовине), војвода (у дроњцима, са звонима око појаса и ногу), свекар и свекрва (у дроњцима, свекар носи мачугу са задебљањем, а свекрва корпу са лутком/дететом), поп (уместо кадионице има стару кутију са жаром и сувом паприком коју кади, бакрач са водом и метлицом уместо босиљка, којом шкропи) и остали сватови. Обилазе село на коњима и, уз пратњу музике, изводе разуздане игре и благосиљају за плодност, а свекар штапом напада невесту и фингира полни акт. Када се опход заврши, обавља се чин венчања око неког дрвета, после чега настаје игранка, уз страховито ударање и пометњу (Антонијевић 1971: 181; Антонијевић 1997: 57-58). Сличан сценарио и подела улога забележени су и у покладним извођењима свадбе у другим крајевима (в. Грбић 1909: 31-32; Петровић 1948: 237-239; Зечевић 1972: 401), а описане сцене венчања младих које изводи тобожњи свештеник је за овај тип маскирања ,jedna od najpristojnijih formi izražavanja ideje plodnosti " (Плотњикова 2000: 74).

Поменуте обредне игре се, по свом карактеру, шаљивом тону и начину извођења, у потпуности могу изједначити са карневалским облицима које Бахтин дефинише као „obredno-predstavljačke forme organizovane na načelima smeha” и које су „bliske pozorišno-predstavljačkim formama po svom vidljivom, konkretno-čulnom karakteru i prisustvu snažnog elementa igre” (Бахтин 1978: 13).

Наведена Бахтинова мисао на најбољи начин показује колико су нераскидиво повезани живот, односно култ плодности и обредна игра, што се у нашој фолклорној традицији најбоље одсликава у примерима чија је тема свадба, која је сама по себи обред који у својој суштини садржи управо наведене идеје. Због тога су тзв. дивље свадбе и игре на сијелима у којима се инсценирају главне фазе свадбеног обреда биле веома заступљене, будући да се у периоду месојеђа (од Божића до Беле недеље) обично „приређују седељке, прошевине девојака и свадбе" (Петровић 1948: 234). Карневалске свадбе притом су представљале својеврсну припрему младих за брак, што је у напоменама појединих записивача и наглашено: „У време Месојеђа [...] обично се сијели у оним кућама у којима је била свадба. Ту долазе момци из околних села, и искупе се из сусједства и мушки и женске" (Мићевић 1952: 155).

Начин на који се приказује свадба, са свим кључним фазама - од припреме дарова до увођења младе у нови дом, у складу је са свеопштом владавином смеховног начела у периоду када су се изводиле ове игре, што се у потпуности подудара са Бахтиновом теријом о карневалском извртању света наопако (в. Бахтин 1978: 18).

Као незаобилазна припремна фаза ступања у брак у традиционалној култури сматрана је припрема дарова за младожењу и све његове ближе сроднике, што је на комичан начин представљено у игри „Удавати ђевојку” 
(Врчевић 1868: бр. 21). Наиме, девојка због своје лењости није успела да припреми дарове на време, што играч који је води и приказује публици тумачи тако што тобоже оправдава понашање које је иначе традиционална заједница строго осуђивала:

Ево овој сироти ђевојци испала срећа да се удава, а оца ни матере нити браће има; дворила је туђу кућу, дворила па ништа не издворила; по ноћи спавала, а дању дријемала; зими се код ватре гријала, а љети се у хладу чешљала; еле укратко да вам кажем: много се мучила, а ништа не измучила [...].

Исти сиже има и игра „Сироте ђевојке”, а у обе се недостатак дарова надокнађује тако што јој гледаоци тобоже поклањају по нешто од своје одеће: чарапе, опанке, кошуљу, гуњ, прегљачу, мараму, струку и сл. У знак захвалности она сваком дариваоцу пољуби руку, али притом међу зубима неприметно држи иглу или трн (драчу), па се комичан ефекат овде постиже тако што их убоде у руку или друге делове тела (образ, колено), док присутне девојке или младе невесте „не убоде иглом но угризне зубима” (Врчевић 1889: бр. 6). Они које је убола узвраћају јој најчешће шаљивим клетвама и тако се игра завршава. Припрема дарова за свадбу је уводна сцена и у игри Бабе $u$ дјевојке, у којој се један играч обуче као стара баба са дрветом у зубима и подупире се штапом, у недрима има бочицу воде, а о рамену торбу пуну луга и балеге, док њена ћерка носи преслицу и драгу, те притом пева: „Предем, предем мајчину куђељу, / Чувам, чувам бабова говеда; / Ђаво спржи мајчину куђељу, / Вук поклао бабова говеда, / Врцкам, врцкам, да се боље прцкам, / J- - - -а сам, весела сам, / И ако сам, нека сам, / Драго ми је и опет ћу!”, да би у следећој сцени затражила од мајке да је што пре уда, али мајка одгађа жељену свадбу са образложењем: „Стани мало, шћери моја, / Док опредем лан / И сакупим дар!” (Братић 1905: 120-125).

У игри „Пољевачина” на шаљив начин приказују увођење младе у нови дом, када је девери по први пут представљају младожењиним рођацима. Она им се у знак поштовања клања и љуби их у руку. И у овој игри присутни су мотиви свадбеног даривања од стране присутних гостију, а млада им се захваљује тако што их, приликом „смерног” клањања и љубљења у руку, попрска водом која је добро скривена у посуди испод одеће. На све то јој узвраћају шаљивим коментарима, псовкама и клетвама, чија је главна сврха изазивање свеопшег смеха (Врчевић 1889: бр. 5).

Исмевање сватовских законика (првенац, барјакатар, кум, војвода, стари сват, девери, муштулугџије) тема је игре „Сватова у крилу” (Братић, Делић 1905: 100) и њене краће варијанте „Сватова” (Павићевић 1934: 114-115). У обе варијанте главни покретач комичне радње је лик набигузице, ${ }^{5}$ ког као непожељног уљеза у сватовској поворци истерују из собе, те га двојица играча дочекују и гараве по лицу, а потом то чине и са осталим сватовским старешинама. У другој варијанти један од играча га удара чарапом пуном пепела или

\footnotetext{
${ }^{5}$ У Српском рјечнику (1852) Вук Караџић објашњава значење овог појма, тумачећи га као део шаљиве сватовске терминологије: „Сви сватови који немају службе у шали зову се набигузице или пустосватице” (Караџић 1852: 377).
} 
појасом са везаним чворовима, а набигузица бежи како би избегао ударце, да би се на крају све, као и у претходном примеру, претворило у свеопшту тучу. Слично се завршава и прва варијанта, у којој „сватови скачу по чељади и гледају да кога огаре, трљајући својим образима по његовим, а после смеха и шале, сватови изађу из собе и умију се" (Братић, Делић 1905: 100).

Описани поступци мазања лица катраном (гаром/чађу) или међусобно посипање играча пепелом није само комичан чин, уколико узмемо у обзир имплицитно присутну апотропејску функцију ових радњи: за катран се верује да тера нечисту силу јаким мирисом (в. Ђорђевић 1985: 159-160, уп. СМ: 264-266), а иста магијска моћ приписивана је и пепелу, који поред ове има још и плодотворну функцију, па су се због тога њиме посипале баште, њиве и воћњаци, као и простор око домаћинстава (в. СД 3: 666-671). Туча и ударање такође су имали ритуално-магијску функцију, те су због тога ови поступци били уобичајени у обредима календарског и животног циклуса (в. СД 1: 177-180, уп. Раденковић 2004: 187).

Комично представљање главних учесника сватовске поворке тема је и игре „Сватова на коњима”, али су у њој присутни разноврснији мотиви: од вођења младе у нови дом, шаљивог наздрављања муштулугџијама испред младожењиног дома крњавом посудом - бардаком, у којој је уместо вина буњиште, на шта им ови узвраћају зарђалом посудом да пију из ње, док им присутне жене уместо дара обесе дроњаве и прљаве крпе, затим следи увођење младе и шаљиво сејање пепела из решета уместо пшенице, предавање накоњчета (уместо детета дају јој мачку или штене) и пародије црквеног венчања на крају (Братић, Делић 1905: 102-104).

На основу приказаних кратких описа може се јасно уочити да се смеховно извртање праве свадбе у овим играма изводи на више нивоа и то пре свега на акционалном и предметном плану. Преоблачење и маскирање били су неизоставни део, а као костими користиле су се, као што и наводе при описима игара „старе издеране рутине” (Холуб 1927: 36), односно

[...] подеране хаљине, што могу горе, затакну за појасеве кратку дрвљад мјесто пушака и ножева, а о рамену обесе торбу луга уместо фишека са барутом [...] Узјашу на дуге сохе уместо коња [...] Напред иду два првијенца, а за њима барјактар, носећи на дрвету какву крпу уместо барјака [...] (Братић, Делић 1905: 102-104).

Поред тога, за маскирање лица углавном су се користили пепео, брашно или чађ (Холуб 1927: 36). Прерушавање је представљало ,jedan od obaveznih momenata narodno-prazničnog veselja”, поред истицања принципа материјално-телесног доле и читавог система снижавања, преокретања и травестирања (в. Бахтин 1978: 96). Притом су елементи травестије најзаступљенији приликом представљања женских ликова (углавном младе), пошто су у свим играма учествовали искључиво млађи мушкарци, па је у овом случају долазило до једностране инверзије полова. ${ }^{6} \mathrm{O}$ томе и записивачи остављају податке у

\footnotetext{
${ }^{6}$ Говорећи о преоблачењу у одећу супротног пола, Мирча Елијаде је објашњава као обредну андрогинизацију, која је честа приликом иницијације младих, због неопходности да неофити током обуке обједињују у себи оба пола, да би на тај начин спознали модус тоталног бивствовања.
} 
виду узгредних коментара: „Обуче се један шаљив момак у ђевојачке хаљине, преметне убрусац про главе, и огрне се са струком (Врчевић 1889: бр. 6); Једног играча обуку у женско одело и претуре му на главу какве крпе уместо мараме, те им је то девојка" (Братић, Делић 1905: 102-104) и сл. Осим што су се преоблачили, играчи су дочаравали различите ликове и тако што „мењају природни глас, местимично подражавају женски или испуштају поједине гласове у говору" (Холуб 1927: 36).

Поред већ поменутих облика изокретаға уобичајеног поретка преодевањем (костимирањем и маскирањем), променом гласа, употребом комичних реквизита, у овим играма неизоставна су и различита поигравања на вербалном плану. Због тога су дијалози, иако углавном импровизовани на лицу места, пуни досетки и шала које се заснивају најчешће на игри речи, односно извртањима њиховог значења променом гласова (чиме се добијају речи сличног звучања, али чији је смисао потпуно различит), као у следећем примеру: „него тако вам њезине муке и јада, смилујте се и подарите ко је што кадер за севап, а за ваше бравље (здравље) и за бабову сушу (душу)” (Врчевић 1868: 16), затим шаљивим здравицама, благословима, клетвама и псовкама, што су све неизоставни елементи празничног слободног говора. Бахтин притом посебно идваја тзв. псовке-срамословља за које тврди да су некада биле саставни део древних смеховних култова и због тога имају амбивалентан карактер - рушећи и уништавајући, оне су истовремено обнављале и препорађале (в. Бахтин 1978: 23-25), што је несумњиво била исконска функција и наведених примера. Треба свакако нагласити да је приликом изговарања ових реплика потпуна слобода била дозвољена не само извођачима, него и свима у публици, који су са њима ступали у шаљиви дијалог током извођења појединих сцена. Управо у овим дијалозима спонтано проговарају различити гласови из публике, као што нам то описује један сакупљач у напомени уз игру у чијој завршној сцени млада полива водом (скривеном у недрима) све присутне, који јој узвраћају тако што „сваки у смијеху по нешто рече, да се други смију [...] куну је, псују је, отискују рукама, а већина говори: Алал ти било с водом из њедара, само немој с оном од оздо" (Врчевић 1889: бр. 5). Слична „проклињања” младе узвикују и приликом извођења сцене када она љуби присутне у руке, али притом држи иглу или трн међу зубима. Онај кога заболи, обично „завиче у шали: [...] отровнијех уста у ове пашјаке ђевојке”; а други му одговори: „Није отровних уста, богме, него језика, па пецне као змија из процијепи”; а трећи: „Није ни уста ни језика, него зла срца а пашјих зубова...” (Врчевић 1868: бр. 21) или: „Оштра језика у ове ђевојке, убио је Бог!” - Други: „А ево јој је језик грђи но у змије - Не љуби више, земља те пољубила, да Бог да!” (Врчевић 1889: бр. 6).

Исту функцију имали су и погрдни изрази у дијалозима који се одвијају између чланова тобожње сватовске поворке и гледалаца. На самом почетку ове игре домаћин уводи сватове у собу (заправо сцену на којој ће се одвијати

О томе више у: Елијаде 1996: 81-84. О кључним елементима инверзије полова у обредној пракси в. Шкрбић Алемпијевић 2006: 42. 
драмска радња), обраћајући се присутнима: „Ево, људи, сватова! Јесте ли их икада поганијих и поср...jих видјели, но што су ови?” - на шта ови одговарају у истом тону: „У погана домаћина погани и сватови, након чега настаје смијех и бука, како то напомињу записивачи" (Братић, Делић 1905: 100).

У коментару уз игру „Удавати ђевојку” у којој се један од учесника захваљује публици на даровима, тако што изриче шаљиве и опсцене благослове, записивач објашњава зашто није објавио и њихов текст у целини: „Изостављам начин благосова и захваљивања, јер не само што би одвећ дуго било све наособ доказујући, него нешто мало и стидно премда се народ у опће при овој игри у сав грохот насмијава" (Врчевић 1868: бр. 21). Тако поступају и његови следбеници, који такође не наводе текст шаљивих благослова дословце, вероватно због истих оних разлога које је и Врчевић изнео: „[...] но све су здравице таке да испадају зло по домаћина и смијешне су - већ како који играч зна и умије" (Братић, Делић 1905: 103).

Шаљиви карактер благослова у појединим сценама могуће је одгонетнути само на основу познавања целокупног контекста, што је случај у игри Сватова на коњима, када тобожњој млади донесу уместо уобичајеног сита (решета) у којем су семенке житарица, решето пуно пепела. Комична замена заснива се на томе што млада уместо њих разбацује пепео по окупљенима, али притом узвикује: Родило! - што је благослов који се иначе изговарао у правој свадби, како би се призвала свеопшта плодност. Потпуна неподударност текста и контекста присутна је и у сцени кад „поп” након извршеног венчања благосиља младенце: „Сретно вам било и дјеца вам се на накоњче уметала! - при чему се ефекат смеховног заснива опет на комичној замени, jep су млади претходно, уместо детета као накоњчета, предали мачку или штене” (Братић, Делић 1905: 103).

Слична изокретања стварности извор су смеха и приликом церемонијалне размене здравица и поздрава које преносе муштулугџије, који пружају сватовима са младине стране зарђалу посуду да из ње наздраве: „Поздравио вас је господин стари сват и остала кита и сватови; добро је, мирно је и здраво, па им се надајте и конак справљајте, а послао вам је ову лубеницу!" - Они му се на томе захваљују: „Хвала му на овоме дарку - златноме бардаку”; заузврат им нуде да пију из неке крњаве посуде у којој је уместо вина буњиште: „А поздрав ћете и ви старом свату и осталој господи сватовима и понесите им ову лубеницу!" - Кад муштулугџија однесе ту посуду старом свату, овај наздравља и изриче свој шаљиви благослов: „Еј вала му чину лијепу и образу свјетлу! [...] Како овај бардак био пун вина, онако у нашега брата домаћина кућа била пуна сваке среће!” Затим тај бардак преузима војвода и благосиља у истом тону: „Хвала брату домаћину на златноме бардаку! Све му овако било златно, чисто, умивено и опрано!” (Братић, Делић 1905: 102-103).

Описана међусобна размена шаљивих реплика, при чему се подразумевало да свако мора да истрпи и шалу на свој рачун, ${ }^{7}$ потврђују Бахтиново

\footnotetext{
7 Записивачи ове врсте умотворина, који из позиције гледалаца прате не само дешавања на импровизованој сцени, него и све оно што се дешава у публици, у потпуности се слажу да се ни најслободније шале не схватају као лична увреда, нити се због њих игра било кад прекида,
} 
запажање да „karneval ne zna za podelu na izvođače i gledaoce, jer bi rampa razorila karneval, koji se ne posmatra nego se u njemu živi, i u njemu žive svi” (Бахтин 1978: 13). Дакле, управо у наведеним примерима сачувана је исконска функција обредног смеха и слободног, у појединим моментима чак и разузданог понашања које га је пратило, а она се у суштини сводила на буђење живота, обнову и ускрснуће природе (в. Проп 1984: 146-148). Управо због тога сви разматрани примери у којима се приказује шаљива свадба, али и драмске игре у којима се на такав начин третирају неке друге теме, представљају драгоцену и инспиративну грађу за проучавање народне смеховне културе.

\section{ЛИТЕРАТУРА}

Антонијевић 1971: Д. Антонијевић, Алексиначко поморавље, Српски етнографски зборник, LXXXIII, Београд: САНУ.

Антонијевић 1997: Д. Антонијевић, Дромена, Београд: Балканолошки институт САНУ.

Бахтин 1978: M. Bahtin, Stvaralaštvo Fransoa Rablea i narodna kultura srednjega veka i renesanse, Beograd: Nolit.

Бојанин 2009: С. Бојанин, Меснице - средњовековни назив за зимски мрсни циклус, Гласник Етнографског института САНУ, LVI I (1), Београд: $107-117$.

Братић, Делић 1905: Т. А. Братић и Ст. Делић, Народне игре са сијела и збора у Горњој Херцеговини, Гласник Земаљског музеја у Сарајеву, XVII, $53-172$.

Врчевић 1868: В. С. Врчевић, Српске народне игре које се забаве ради по састаниима играју, Кьига I, Београд: Српско учено друштво.

Врчевић 1889: В. С. Врчевић, Српске народне игре које се забаве ради по састанцима играју, Кюига II, Дубровник: Наклада књижаре Драгутина Претнера.

Грбић 1909: С. М. Грбић, Живот и обичаји народни у срезу бољевачком, $C p$ пски етнографски зборник, XIV, Београд: СКА.

Ђорђевић 1958: Д. М. Ђорђевић, Живот и обичаји у Лесковачкој Морави, Српски етнографски зборник, LXX, Београд: САНУ.

Ђорђевић 1985: Т. Р. Ђорђевић, Зле очи у веровағу Јужних Словена, Београд: Просвета.

Елијаде 1996: M. Elijade, Mefistofeles i Androgin, Čačak: Dom kulture Čačak, Umetničko društvo „Gradac.”

јер се у игри „ништа не замјера” (Грђић Бјелокосић 1907: 92), „нити се икада ико у ономе часу наљути, па макар му се што неприлично рекло или учинило" (Врчевић 1868: б. с.), односно све се одиграва „наочиглед радозналих посматрача и домаће чељади без икаквог негодовања и замерке” (Петровић 1948: 238). 
Зечевић 1972: S. Zečević, Pokladne igre u Gruži, Rad XVII kongresa Saveza udruženja folklorista Jugoslavije u Poreču 1970. godine, Zagreb, 401-403.

Зечевић 2008: С. Зечевић, Српска етномитологија, приредили Б. Јовановић, Б. Зечевић, Београд: Службени гласник.

Јокић 2011: Ј. Јокић, Врчевићеве збирке српских народних игара као извор за проучавање народне драме, Годишњак Катедре за српску књижевност са јужнословенским књижевностима (Посвећено успомени на проф. $\partial p$ Радмилу Пешић), VI, Београд, 85-97.

Јокић 2013: Ј. Јокић, Бележење и проучавање традиционалних драмских форми на простору Босне и Херцеговине у 19. и 20. веку, Зборник радова са научног скупа „Наука и традииија”, Пале: Филозофски факултет, 691-702.

Карановић, Јокић 2007: 3. Карановић, Ј. Јокић, Обредни жанрови и књижевне врсте у покладним ритуалима, Синхронијско и дијахронијско изучавање врста у српској књижевности, Зборник радова, књ. 1, ур. 3. Карановић, Нови Сад: Филозофски факултет - Дневник, 5-22.

Карановић, Јокић 2009: 3. Карановић, Ј. Јокић, Смеховно и еротско у српској народној култури и поезији, у трагању за заборављеним значењима смеха у усменој традищији - од култа плодности до карневала, Нови Сад: Филозофски факултет.

Карановић, Јокић 2011: 3. Карановић, Ј. Јокић, Обредни смех у песмама зимског календарског циклуса, Годишњак Филозофског факултета у Новом Саду, XXXVI/1, 163-177.

Караџић 1852: В. Стеф. Караџић, Српски ријечник истумачен њемачким и латинскијем ријечима (1852), Сабрана дела Вука Караџића, Књ. 11, приредио Ј. Кашић, Београд: Просвета, 1986.

Милићевић 1894: М. Ђ. Милићевић, Живот Срба сељака, Српски етнографски зборник, I, Београд: СКА.

Мићевић 1952: Љ. Мићевић, Живот и обичаји Поповаца, Српски етнографски зборник, LXV, Београд: САНУ.

Недељковић 1990: М. Недељковић, Годишњи обичаји у Срба, Београд: „Вук Караџић”.

Николић Стојанчевић 1974: В. Николић Стојанчевић, Врањско Поморавље: етнолошка испитивања, Српски етнографски зборник, LXXXVI, Београд: САНУ.

Павићевић 1934: M. Pavićević, Narodne igre u Crnoj Gori, Zbornik za narodni život i običaje Južnih Slavena, knj. XXIX, sv. 2, Zagreb, 91-118.

Петровић 1948 П. Ж. Петровић, Живот и обичаји народни у Гружи, Српски етнографски зборник, LVIII, Београд: САНУ.

Плотњикова 2000: A. Plotnjikova, Erotski elementi u južnoslovenskim maskirnim ophodima, Erotsko u folkloru Slovena, priredio Dejan Ajdačić, Stubovi kulture, Beograd, 73-80.

Проп 1984: V. Prop, Problemi komike i smeha, preveo Bogdan Kosanović, Novi Sad: Dnevnik. 
Раденковић 2004: Љ. Раденковић, Ударање у обредима животног круга, Кодови словенских култура, 9, ур. Д. Ајдачић, Београд, 182-188.

СД: Славянские древности. Этнолингвистический словарь. Т. 1-5. Под ред. Н. И. Толстого и др. Москва: „Международные отношения,” 1995-2012.

СМ: Словенска митологија: енциклопедијски речник, (ред.) С. М. Толстој и Љ. Раденковић, Београд: Zepter Book World.

Филиповић, Томић 1955: М. С. Филиповић, П. Томић, Горња Пчиња, Сpnски етнографски зборник, LXVIII/3 (IV одељење. Расправе и грађа), Београд: САНУ.

Холуб 1927: И. Холуб, Нешто о селима, прелима и народним играма у Попову Пољу (Херцеговина), Гласник Етногрфског музеја у Београду, II, Београд, 35-41.

Шкрбић Алемпијевић 2006: N. Škrbić Alempijević, Inverzija spolova u hrvatskim pokladnim i svadbenim običajima, Narodna umjetnost, 43/2, 41-65.

Jasmina S. Jokić

\title{
CARNIVALIZATION OF THE WEDDING RITUAL IN ORAL DRAMA FORMS
}

\author{
(Summary)
}

The paper starts with Bakhtin's interpretation of the carnival as the second, festive life of their people, as well as the process of carnivalization, that is, the transfer of the carnivalesque - the principle of laughter, into various art forms. That is why the subject of this paper will be various elements of carnivalization in so called folk plays, which represent rudimentary forms of oral dramas. The research is based on diverse ethnographic sources and drama elements in rites which were performed during the time of winter mrsni [meat-eating] period, the so called mesojeđa/mesnica and poklada [carnival]. We discuss examples in which a wedding is staged in a comical manner, which is one of the crucial rites in the circle of life and is the most complex rite of transition in Serbian traditional culture. It is noticeable that in the oral tradition main participants in the wedding are portrayed in a uniform way, with the necessary presence of the elements of inversion of gender through disguises (ritual travesty), hyperbolic corporality (especially of lower body parts and reproductive organs), lascivious behaviour and obscene vocabulary (swear words, jocular blessings and curses etc.), which are all typical elements of traditional culture of laughter. 